\title{
Komunikasi Organisasi Keagamaan dalam Melakukan Pendekatan Secara Daring untuk Mengupayakan Keaktifan Anggota Selama Masa Pandemi
}

\author{
Christian Calvin ${ }^{1}$, Riris Loisa $^{2^{*}}$ \\ ${ }^{1}$ Fakultas Ilmu Komunikasi, Universitas Tarumanagara, Jakarta \\ Email: Christian.915180071@fikom.untar.ac.id \\ ${ }^{2}$ Fakultas Ilmu Komunikasi, Universitas Tarumanagara, Jakarta* \\ Email: ririsl@fikom.untar.ac.id
}

Masuk tanggal : 15-12-2021, revisi tanggal : 06-01-2022, diterima untuk diterbitkan tanggal : 06-01-2022

\begin{abstract}
This study describes communication within religious organizations to make online approaches to their members during the pandemic and get an overview of the activities of members of religious organizations through organizational communication. How is the spiritual activity of members of the religious organization GBI Daan Mogot, West Jakarta. Using a qualitative research approach, a case study was conducted on the GBI Daan Mogot congregation. Data collection techniques using interview techniques. Interviews were conducted to support the reality that spiritual activity must start from a clear structure and purpose of the organization itself. From the results of in-depth interviews that the author conducted, it shows that the church communicates with its members through the community, computer-mediated communication that facilitates worship, and deepening of religion through discussion after worship by community members. Social media also plays a big role in providing information regarding access to worship through online during the pandemic.
\end{abstract}

Keywords: communication organizations, communities, GBI Daan Mogot, spiritual activity

\begin{abstract}
Abstrak
Penelitian ini mendeskripsikan komunikasi di dalam organisasi keagamaan untuk melakukan pendekatan secara daring kepada anggotanya selama masa pandemi dan mendapatkan gambaran keaktifan anggota organisasi keagamaan melalui komunikasi organisasi. Bagaimana keaktifan rohani anggota organisasi keagamaan GBI Daan Mogot, Jakarta Barat. Dengan menggunakan pendekatan penelitian kualitatif, studi kasus dilakukan pada jemaat GBI Daan Mogot. Teknik pengumpulan data dengan menggunakan teknik wawancara. Wawancara dilakukan untuk mendukung realita bahwa keaktifan rohani harus dimulai dari struktur dan tujuan yang jelas dari organisasi itu sendiri. Dari hasil wawancara mendalam yang penulis lakukan, menunjukkan bahwa gereja melakukan komunikasi terhadap anggotanya melalui komunitas, komunikasi termediasi computer yang mempermudah ibadah, dan pendalaman agama melalui diskusi setelah ibadah oleh anggota komunitas. Media sosial juga berperan besar dalam memberi informasi mengenai akses ibadah melalui online di saat pandemi.
\end{abstract}

Kata Kunci: komunikasi organisasi, komunitas, GBI Daan Mogot, keaktifan rohani

\section{Pendahuluan}

Pada masa pandemi Covid-19 ini, inovasi dari teknologi sangat membantu aktivitas orang - orang yang ingin bertatap muka selama PPKM ini, khususnya ibadah secara online. Pandemi menyadarkan jemaat Kristen untuk berpegang teguh dalam iman dan beribadah kepada Tuhan, bahkan diharapkan untuk meningkatkan iman dan 
percayanya kepada Tuhan Yesus Kristus sang juru selamat. Untuk itu dengan perkembangan teknologi yang semakin pesat, sekarang ibadah online dapat diadakan via aplikasi Zoom (Langfan, 2021).

Dengan kehadiran aplikasi Zoom, membuat jemaat tetap bisa melakukan ibadah secara virtual seperti ibadah secara daring, dan juga komsel secara daring. Perubahan suasana kehidupan jemaat akan terus menuntut metode hidup serta ibadah yang berbeda. Perlu disadari jika, tempat beribadah akan senantiasa terletak dalam masa transisi, serta tidak sempat terletak dalam kondisi tetap maupun permanen. Konteks masa kini, kita berhadapan dengan konteks kebudayaan serta agama tradisional di satu pihak, tetapi kita pula bergumul dengan konteks modernisasi yang dengan nyata jadi bagian hidup warga yang mendatangkan pergantian nilai (pola pikir/penafsiran/penghayatan). Walaupun kondisi demikian tetapi dengan terdapatnya kemajuan teknologi bisa dimanfaatkan buat beribadah secara online dengan fasilitas virtual meeting lewat aplikasi zoom ataupun live streaming. Kebaktian online jadi alternatif untuk pendeta serta sesama jemaat bisa bersekutu dengan Tuhan, tetapi ibadah online dikenal tidak sangat signifikan sebab lewat ibadah online tidak seluruh jemaat bisa beribadah dengan serius serta bisa mencermati firman Tuhan dengan baik sebab pengaruh dari suasana yang berbeda (Langfan, 2021).

Penelitian ini berlatar belakang bagaimana komunikasi organisasi keagamaan GBI Daan Mogot, Jakarta Barat, dalam mengupayakan pendekatan secara daring untuk mengupayakan keaktifan anggotanya. Sedangkan tujuan diadakannya penelitian ini adalah agar mendapat gambaran mengenai komunikasi didalam organisasi keagamaan untuk melakukan pendekatan secara daring kepada anggotanya selama masa pandemi dan mendapatkan gambaran keaktifan anggota organisasi keagamaan melalui komunikasi organisasi secara daring di masa pandemi.

Arnus dalam (Kapriadi 2020) mengatakan jika computer mediated communication (CMC) timbul bersamaan dengan pertumbuhan teknologi komunikasi serta online secara cepat, dimana jangkauan dari CMC dalam bentuk seperti chat, blog website, serta lain-lainnya. Pola CMC memunculkan perpindahan pola komunikasi yang terjalin dalam anggota organisasi keagamaan semacam pola komunikasi dimana dulunya dicoba secara luring, disaat ini membolehkan buat dicoba melalui sosial media ataupun aplikasi seluler semacam aplikasi mobile GBI Daan Mogot.

Selayaknya ibadah offline, maka ibadah yang diadakan secara online juga pastinya membutuhkan komunikasi untuk tetap menjaga hubungan antara jemaat dan organisasi gereja itu sendiri. Menurut Sulistyo (dalam Panuju and Narena, 2019) Komunikasi organisasi merupakan penyampaian serta penerimaan berbagai pesan organisasi di suatu kelompok yang resmi atau tidak resmi dari organisasi tersebut. Dipaparkan juga kalau komunikasi resmi adalah komunikasi yang dirembukkan oleh organisasi serta sifatnya mementingkan kepentingan dari organisasi itu sendiri. Ada pula komunikasi informal adalah komunikasi yang telah dirembukkan secara sosial, yang tidak berpihak pada organisasi, namun lebih kepada anggotanya selaku individual. Kenyataan dalam suatu riset menampilkan kalau komunikasi yang bertabiat informal mempunyai daya guna dalam komunikasi organisasi.

Menurut Panuju dan Narena (2019) Komunikasi organisasi yang mirip dengan komunikasi internal. Definisi komunikasi internal adalah pertukaran gagasan di antara para pendeta serta jemaat dalam suatu organisasi keagamaan, dalam struktur lengkap yang umumnya diiringi pertukaran pendapat secara horizontal serta vertikal di dalam suatu organisasi keagamaan, sehingga pembagian tugas dapat dilakukan. Gereja memiliki struktur organisasi yang bersifat keagamaan. Pada masa pandemi, 
komunikasi organisasi gereja terjalin via daring. Salah satu contoh gereja yang menerapkan ibadah via daring adalah GBI Daan Mogot.

\section{Metode Penelitian}

Penelitian yang akan dilakukan oleh penulis ini memanfaatkan metode riset kualitatif yang dimana riset menciptakan penemuan - penemuan yang tidak bisa diperoleh dengan memakai prosedur- prosedur statistik ataupun cara-cara lain dari kuantifikasi (pengukuran).

Penelitian kualitatif lebih memfokuskan pada pemanfaatan diri sang peneliti selaku instrumen. Lincoln serta Guba (dalam Mulyadi, 2013) menyatakan jika dalam pendekatan kualitatif peneliti seyogyanya menggunakan diri selaku instrumen, sebab instrumen non manusia susah digunakan secara luwes guna mengumpulkan bermacam kenyataan serta interaksi yang berlangsung. Peneliti wajib dapat menguak indikasi sosial di lapangan dengan mengupayakan segenap peranan inderawinya. Dengan demikian, peneliti wajib sanggup diterima oleh informan serta lingkungannya supaya dapat menguak informasi yang tersembunyi lewat bahasa tutur, bahasa badan, sikap ataupun ungkapan- ungkapan yang tumbuh dalam dunia serta daerah informan.

Menurut Sugiono (dalam Hadi, 2016), metode penelitian adalah cara ilmiah untuk mendapatkan data/informasi sebagaimana adanya dan bukan sebagaimana seharusnya, dengan tujuan dan kegunaan tertentu. Metode penelitian yang digunakan dalam penelitian ini adalah Studi Kasus. Metode Studi Kasus adalah metode penelitian yang dilakukan dengan mengangkat suatu kasus, bisa berupa organisasi, sekelompok orang, komunitas, sebuah peristiwa (event), suatu proses, isu atau kampanye.

Dalam melaksanakan metode pengumpulan data agar mendukung hasil penelitian, penulis menggunakan metode dalam pengumpulan data, yaitu Metode Wawancara Mendalam. Wawancara mendalam (in depth interview) sendiri menggambarkan tata cara pengumpulan informasi yang kerap digunakan dalam riset kualitatif. Wawancara mendalam secara universal merupakan proses mendapatkan keterangan guna tujuan riset dengan metode tanya jawab sambil bertatap muka antara pewawancara dengan informan ataupun orang yang diwawancarai, dengan atau tanpa memakai pedoman wawancara, pewawancara, serta informan ikut serta dalam kehidupan sosial yang relatif lama. Dengan demikian, kekhasan wawancara mendalam merupakan keterlibatannya dalam kehidupan informan (Tanzeh, 2011).

Supaya wawancara dapat berlangsung dengan baik untuk memperoleh informasi yang diinginkan, petugas wawancara maupun periset wajib menghasilkan atmosfer yang akrab sehingga tidak terdapat jarak dengan petugas wawancara dengan orang yang diwawancarai. Ada pula kelebihan pengumpulan informasi dengan teknik wawancara merupakan informasi yang dibutuhkan langsung diperoleh sehingga lebih akurat serta bisa dipertanggung jawabkan (Tanzeh, 2011).

Metode in-depth interview ini digunakan guna mewawancarai kepala persekutuan organisasi keagamaan GBI Daan Mogot, pimpinan persekutuan doa, dan juga sebagian anggota kelompok (family cell) dari organisasi keagamaan tersebut. Tata cara ini digunakan guna menggali informasi tentang perencanaan, penerapan, serta penilaian organisasi keagamaan GBI Daan Mogot dalam membina keaktifan anggotanya di masa pandemi. 


\section{Hasil Temuan dan Diskusi}

GBI Daan Mogot merupakan salah satu organisasi keagamaan yang mengalami ibadah melalui daring selama masa pandemi. Dalam penelitian terdahulu "Computer Mediated Communication (CMC) dalam Perspektif Komunikasi Lintas Budaya (Tinjauan Pada Soompi Discussion Forum Empress Ki TaNyang Shipper)", komunikasi bermediasi komputer sudah menjadi hal yang lumrah ketika orang berkomunikasi dengan orang yang lain menggunakan sarana komputer, tablet, dan ponsel genggam via daring (Pratiwi , 2014).

Dalam proses pelaksanaan ibadahnya selama masa pandemi, GBI Daan Mogot menggunakan aplikasi Zoom dan live streaming melalui Youtube. Hal tersebut berdasarkan bahwa selama ibadah online berlangsung GBI Daan Mogot tetap ingin anggotanya mengalami keaktifan rohani walau dalam masa pandemi sekalipun dimana membatasi adanya pertemuan secara tatap muka antar anggota.

Berdasarkan data yang telah diperoleh dalam proses penelitian tugas akhir ini GBI Daan Mogot memiliki komunikasi organisasi yang berjalan lancar melalui adanya CMC dan Komunitas sesuai dengan teori yang dicantumkan pada penelitian ini. Pembahasan ini ditulis berdasarkan wawancara mendalam yang penulis lakukan dengan Ketua Organisasi (PPA) dalam GBI Daan Mogot beserta anggota aktif dalam komunitas itu sendiri. Wawancara ini menggali komunikasi didalam organisasi itu sendiri, pendekatan di dalam komunitas, dan hasil keaktifan anggota selama masa pandemi.

\section{Ragam Bentuk Komunikasi dalam Organisasi Keagamaan}

GBI Daan Mogot merupakan organisasi keagamaan yang memiliki struktur komunikasi organisasi yang vertikal dan linear. Dengan adanya struktur didalam organisasi keagamaan maka akan mempermudah proses pemantauan jemaat itu sendiri baik dalam struktur ministry maupun cool. Komunikasi organisasi yang memiliki tujuan untuk menjadi wadah bagi para jemaat agar kerohanian dapat terus bertumbuh didalam gereja selama masa pandemi. Apalagi dengan adanya struktur yang memantau dimana struktur tersebut menjadikan organisasi keagamaan yang umumnya diiringi pertukaran sudut pandang secara horizontal serta vertikal di dalam sesuatu komunitas sehingga tujuan yang ingin dicapai bersama dapat dengan mudah dilakukan dengan adanya struktur yang bersifat vertikal dan linear.

Menurut penjelasan dari narasumber, komunikasi dalam organisasi keagamaan sebagai fungsi pemantauan struktur. Dalam struktur yang kedua yaitu struktur Cool (Komsel). Struktur ini berfungsi untuk mengepalai komunitas atau cool disebutnya yang berfungsi untuk memantau keaktifan / pertumbuhan kerohanian dari masingmasing anggota komunitas itu sendiri. 


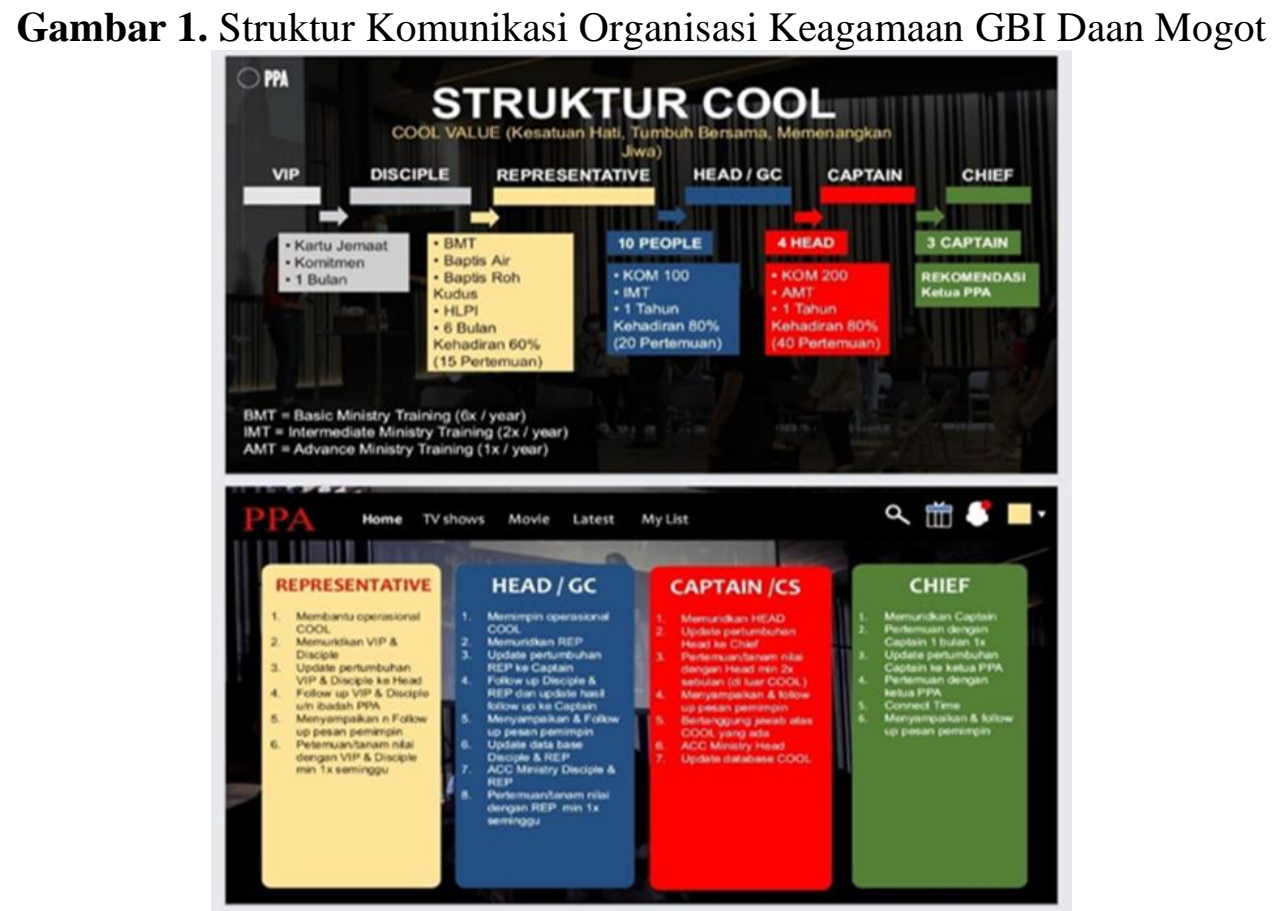

Sumber: Dokumentasi Organisasi Keagamaan

Dari hal di atas maka bisa disimpulkan dengan jelas sesuai dengan pendapat Schein dalam penelitian terdahulu "Communication of Organizations in Organizations Change's Phenomenon in Research and Development Institution." (Romadona dan Setiawan 2020) bahwa dengan adanya struktur komunikasi organisasi yang memantau dimana struktur tersebut menjadikan organisasi keagamaan yang umumnya diiringi pertukaran sudut pandang secara horizontal serta vertikal di dalam suatu komunitas sehingga tujuan yang ingin dicapai bersama dapat dengan mudah dilakukan dengan adanya struktur yang bersifat vertikal dan linear. Organisasi mempunyai ciri tertentu antara lain terdapatnya struktur, tujuan, saling tersambung serta bergantung pada komunikasi manusia di dalamnya, untuk mengkoordinasikan kegiatan organisasi tersebut dalam mencapai tujuan

\section{Ragam Utilitas CMC Selama Masa Pandemi}

CMC menjadi bentuk komunikasi daring yang diterapkan oleh GBI Daan Mogot selama masa pandemi. Menurut hasil wawancara dengan narasumber, CMC memudahkan aktivitas ibadah GBI Daan Mogot di masa pandemi. Dengan keadaan yang serba dirumah dan semuanya dilakukan secara daring dari rumah tapi dengan adanya kemajuan teknologi sekarang ini maka segala sesuatunya bisa dengan mudah mendekatkan mereka yang jauh secara jarak, dalam hal ini contohnya ibadah dilakukan melalui via youtube atau zoom. Dengan begitu, anggota GBI Daan Mogot akan lebih rajin ke gereja karena mereka tidak perlu menempuh jalan yang jauh menuju gereja, sehingga pertumbuhan kedewasaan rohani pada saat daring akan sangat membantu karena tidak ada alasan lagi bagi mereka untuk tidak memiliki kesempatan untuk beribadah.

Dari hal diatas maka bisa disimpulkan dengan jelas sesuai pendapat Larassati (dalam Arnus, 2015) dalam penelitian terdahulu "Computer Mediated Communication (CMC), Pola Baru Berkomunikasi." dengan sarana yang dimiliki media baru, sehingga di dunia yang serba mutakhir ini segalanya dapat dicoba dengan duduk di tempat tanpa 
butuh beranjak dari tempat duduk serta meninggalkan kegiatan seorang. Berdasarkan teori CMC, perihal ini terjalin sebab pesatnya teknologi komunikasi sehingga seorang bisa berbicara kapan serta dimana saja dan tidak terbatas ruang serta waktu. Seorang berbicara dikala ini tidak wajib berjumpa muka ataupun face-to-face dengan lawan komunikasinya, sehingga membolehkan orang-orang senantiasa berbicara dengan seorang dimanapun serta kapanpun.

\section{Tujuan Pendekatan melalui Komunitas}

Interaksi secara merata sebagai cara pendekatan melalui komunitas via online meningkatkan kekompakan. Adanya interaksi yang dibagi secara rata dalam komunitas GBI Daan Mogot dapat meningkatkan rasa kekompakan anggota dalam komunitas itu sendiri. Interaksi yang harus dilakukan di dalam komunitas harus bisa merata ke seluruh anggota komunitas, jadinya semua anggota komunitas itu sendiri harus tau semua hal yang dibahas atau semua hal yang didiskusikan dalam sebuah pertemuan komunitas agar menghindari kesalahpahaman serta dapat meningkatkan kekompakkan antar sesama anggota komunitas. Sehingga tidak ada pihak yang tidak mengetahui segala yang sudah didiskusikan, jadi bisa dikatakan kapasitas hubungan komunikasi yang dilakukan harus sama dengan setiap anggota komunitas.

Sedangkan dalam pendekatan melalui offline atau tatap muka, pendekatan melalui komunitas secara offline dari GBI Daan Mogot berupa konseling. Menurut narasumber, GBI Daan Mogot menyediakan tim khusus untuk konseling, namun untuk masalah kecil misalnya pertengkaran, pacaran, dan lain-lain bisa diselesaikan dengan bantuan ketua komunitas masing-masing.

Dalam pembahasan ini dapat dikaitkan dengan frame of references dimana timbulnya penyetaraan kerangka rujukan demi menyatukan tujuan bersama dalam komunitas GBI Daan Mogot. Dalam penelitian terdahulu "Komunikasi Organisasi Pada Dinas Perizinan Kota Yogyakarta Untuk Meningkatkan Pelayanan." Tujuan komunikasi dalam proses organisasi tidak lain dalam rangka membentuk saling pengertian (mutual understanding). Pendek kata agar terjalinnya penyetaraan dalam kerangka rujukan (frame of references) ataupun bidang pengalaman (field of experiences). (Mulawarman and Rosilawati 2014) Sedangkan menurut teori komunitas, dimana interaksi kegiatan konseling yang diadakan oleh organisasi keagamaan akan mempengaruhi pertumbuhan jemaat apalagi di masa pandemi ini. Apalagi dengan adanya konseling secara khusus berdasarkan rekomendasi dari ketua komunitas itu sendiri. Biasanya konseling diadakan sesuai dengan gender masingmasing. Misalnya laki-laki dengan laki-laki dan perempuan dengan perempuan.

Dengan adanya interaksi mendalam maka secara tidak langsung akan mempererat hubungan antar sesama anggota sehingga anggota dalam komunitas itu akan merasa nyaman dan merasa dipedulikan.

\section{Strategi Keaktifan Anggota}

Hasil keaktifan anggota di masa pandemi berhasil dengan ditemukannya cara untuk meningkatkan pertumbuhan rohani jemaat selama ibadah via daring. Menurut Narasumber, ibadah online pada awalnya tidak terlalu membantu, namun GBI Daan Mogot berhasil menemukan satu formula. Dikarenakan ibadah yang dilakukan melalui zoom dan youtube tidak menimbulkan interaksi, sehingga beberapa bulan kedepan mulai Januari GBI Daan Mogot membuat konsep setelah ibadah ada ibadah bersama untuk berkumpul melalui aplikasi Zoom guna membahas mengenai apa yang didapatkan melalui ibadah. Kemudian GBI Daan Mogot mulai mengadakan interaksi 
melalui QnA jadi komunikasi nya tidak hanya satu arah agar jemaat bisa lebih mengerti apa yang dia mau ketahui dan bisa terjawab. Sehingga jemaat akan bertumbuh karena komunikasi dua arah.

\section{Simpulan}

Berdasarkan hasil penelitian diatas, maka kesimpulan dalam penelitian adalah sebagai berikut: (1) GBI Daan Mogot melakukan komunikasi terhadap anggotanya, yaitu antara lain komunikasi organisasi dalam organisasi keagamaan melalui komunitas, CMC yang mempermudah ibadah, pendekatan melalui interaksi antara ketua dan anggota komunitas, dan pendalaman agama melalui diskusi setelah ibadah oleh anggota komunitas; (2) Banyak gereja yang mengalami penurunan kehadiran anggota selama masa pandemi dimana banyak sekali anggota gereja yang tidak hadir dikarenakan sulitnya mendapatkan akses untuk beribadah. Namun dengan adanya sosial media GBI Daan Mogot yang terus gencar memberitahukan akses ibadah melalui online, maka dengan diterapkannya sistem struktur yang vertikal dan linear akan mempermudah GBI Daan Mogot untuk menjangkau dan terus mengetahui perkembangan rohani yang dialami oleh jemaatnya selama masa pandemi.

\section{Ucapan Terima Kasih}

Penelitian dapat diselesaikan dengan tepat waktu dikarenakan banyak pihak yang menyediakan waktu dalam penelitian ini khususnya Linkent selaku ketua PPA dari organisasi keagamaan GBI Daan Mogot dan semua informan yang terkait dalam penelitian ini. Terima kasih yang sangat besar apresiasinya untuk GBI Daan Mogot dalam proses penelitian gereja ini.

\section{Daftar Pustaka}

Arnus. (2015). Computer Mediated Communication (CMC), Pola Baru Berkomunikasi. Al-Munzir, 8(2), 275-289. Retrieved from https://ejournal.iainkendari.ac.id/index.php/al-munzir/article/view/744/680

Hadi. (2016). Pemeriksaan Keabsahan. Jurnal Ilmu Pendidikan, 74-79.

Kapriadi. (2020). Implementasi Computer Mediated Communication dalam Digital Staffing Berbasis Mobile Application dan Online Platform di Perusahaan Startup. Jurnal.Unhas.Ac.Id/Index.Php/Kareba, 9, 382-399.

Langfan, O. (2021). Ibadah Online di Masa Pandemi Covid-19: Implementasi Ibrani 12:28. Stella: Jurnal Teologi Dan Pendidikan Kristen, I(1), 15-18. Retrieved from http://sttse.ac.id/e-journal/index.php/stella

Mulawarman, K., \& Rosilawati, Y. (2014). Komunikasi Organisasi Pada DInas Perijinan Kota Yogyakarta Untuk Meningkatkan Pelayanan. Jurnal Ilmiah Komkunikasi Makna, 5(1), 31. doi:https://doi.org/10.30659/jikm.5.1.31-41

Mulyadi, M. (2013). Penelitian Kuantitatif Dan Kualitatif Serta Pemikiran Dasar Menggabungkannya. Jurnal Studi Komunikasi Dan Media, 15(1), 128. doi:https://doi.org/10.31445/jskm.2011.150106

Panuju, R., \& Narena, I. K. (2019). Komunikasi Organisasi Bidang Reservasi Hotel. Jurnal Komunikasi, 11(1), 30. doi:https://doi.org/10.24912/jk.v10i1.2297 
Pratiwi, F. D. (2014). Computer Mediated Communication (CMC) Dalam Perspektif Komunikasi Lintas Budaya ( Tinjauan Pada Soompi Discussion Forum Empress Ki TaNyang Shipper). Profetik, 7(1), 29-44.

Romadona, M. R., \& Setiawan, S. (2020). Communication of Organizations in Organizations Change's Phenomenon in Research and Development $\begin{array}{llll}\text { Institution. } & \text { Journal }\end{array}$ doi:https://doi.org/10.30818/jpkm.2020.2050110

Tanzeh, A. (2011). Metodologi Penelitian Praktis. Teras, 64. 